\section{NUMERICAL SIMULATION OF MUDFLOW WITH A TWO-DIMENSIONAL DEPTH-AVERAGED MODEL}

\author{
Puay How Tion*, Lim Jia Jun, Nor Azazi Zakaria
}

River Engineering and Urban Drainage Research Centre (REDAC), Universiti Sains Malaysia, 14300 Nibong Tebal, Pulau Pinang, Malaysia
Article history

Received

26 July 2019

Received in revised form

22 December 2020

Accepted

5 January 2021

Published online

22 April 2021

*Corresponding author

redac_puay@usm.my

\section{Graphical abstract}

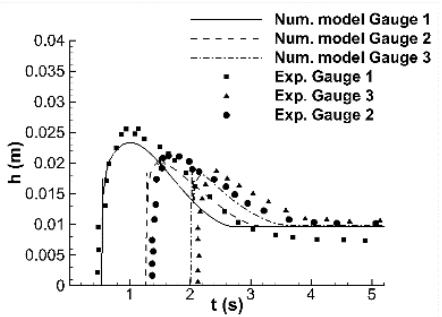

\begin{abstract}
This study is motivated by the need to mitigate damages caused by mudflow disaster, which is occurring frequently due to intensive forest clearing and uncontrolled land use at highland. Numerical modelling of mudflow is challenging as the propagation speed and rheological behavior of the flow relies on the accuracy of the numerical scheme and choice of rheological model. In this study, a two-dimensional depth-averaged model was developed to simulate a simplified mudflow event. In order to capture shock in mudflow, the finite volume method (FVM) with third order accurate Monotonic Upstream-centered Scheme of Conservation Laws (MUSCL) scheme was adopted in the numerical model and the model was verified against a benchmark partial dam-break problem. By assuming that the mudflow has high amount of fine mud suspension. the rheological model was represented by a simplified Herschel-Bulkley model. Numerical results showed that the Herschel-Bulkley model could reproduce the viscoplastic behavior of mudflow well, especially in the estimation of final longitudinal flow spreading ( $2 \%$ difference compared to experimental value) and depth of peak wave (8.8\% maximum difference). The robustness and stability of the model was demonstrated by simulating a simplified mudflow event with obstacles.
\end{abstract}

Keywords: Mudflow, Herschel Bulkley model, viscoplastic fluid, dam-break flow model, shallow water equation

\begin{abstract}
Abstrak
Kajian ini didorong oleh keperluan untuk mitigasi banjir lumpur yang semakin kerap berlaku di kebelakangan ini akibat penebangan hutan yang berleluasa dan penggunaan tanah yang tidak terkawal di kawasan tanah tinggi. Permodelan berangka aliran lumpur adalah mencabar kerana kelajuan aliran lumpur dan sifat reologinya bergantung kepada ketepatan skema berangka dan pilihan model reologi. Dalam kajian ini, satu model berangka dua dimensi berdasarkan persamaan air cetek dibina untuk simulasi aliran lumpur mudah. Untuk menjerap gelombang kejutan di dalam aliran lumpur, kaedah 'finite volume' (FVM) dengan skema berkejituan taraf tiga, iaitu skema 'Monotonic Upstreamcentered Scheme of Conservation Laws (MUSCL)' digunakan. Model berangka ini disahkan dengan sebuah model tanda aras, iaitu model empangan-pecah-sebahagian. Model reologi aliran lumpur diwakili dengan model Herschel-Bulkley dengan anggapan bahawa kandungan lumpur halus adalah tinggi. Hasil model berangka menunjukkan bahawa model Herschel-Bulkley dapat menghasilkan sifat 'viscoplastik' aliran lumpur dengan baik, terutamanya dalam askpek penganggaran jarak bujur akhir ( $2 \%$ perbezaan dengan keputusan eksperimen) dan kedalaman aliran di puncak gelombang (perbezaan maksima sebanyak 8.8\%). Akhir sekali, keteguhan dan kestabilan model ditunjukkan dengan simulasi aliran lumpur dengan objek halangan.

Kata kunci: Aliran lumpur, model Herchel-Buckley, bendalir viscoplastik, model empangan pecah, persamaan air cetek
\end{abstract}

(C) 2021 Penerbit UTM Press. All rights reserved 


\subsection{INTRODUCTION}

Mudflow and debris flow are disasters closely related to mismanagement of land-use in steep terrain. These hazards have claimed hundreds of lives and caused economy losses worldwide [1]. It is therefore important to predict mudflow flow extent for mitigation purposes and engineering countermeasures. Several incidents of mudflow or debris flow in Malaysia have been recorded: along the Titiwangsa ridge - Fraser's Hill, Pahang (2007, 2009), Genting Sempah, Pahang (1995), Lojing-Gua Musang Road, Kelantan (2009), and Cameron Highland (2014). These incidents were triggered by high intensity and long duration rainfall on steep terrain which are often thinly vegetated as the result of deforestation and land-clearing [2].

Mathematical modelling of the constitutive relation of mudflow and debris flow is extremely important as the flow characteristics are governed by the shear stress-strain rate relation. The Bingham model is often used to represent the constitutive relation for mudflow and debris flow because these fluids possess yield stress which can bring the flow into a complete halt, or rest state. Such representation of mudflow and debris flow using Bingham model can be seen in the work of Schamber and MacArthur [3] and O'Brien [4]. Takahashi and Tsujimoto [5] used the dilatant-fluid model with Coulomb flow resistance in their simulation of debris flow. The use of Herschel-Bulkley model to simulate mudflow and debris flow can be seen in the work of Laigle and Coussot [6] and Huang and Garcia [7].

The inertia of flow on an inclined plane can be dominant. Therefore, to simulate flow on a steep slope, the inclusion of the inertia term in the governing equation of motion is important. The inclusion of inertia term in the study of mudflow can be seen in the work of Fernandex-Nito et al. [8] where the topography and inertia effects are included in the viscoplastic model. Ionescu [9] also included the inertia effect in the modelling of shallow avalanche onset. Therefore, solving the advection term accurately is critical to reproduce correct inertial characteristic. In addition, mudflow is characterized by shocks and sharp fronts [6]. These features cannot be captured by first order scheme, which is numerically diffusive [10]. Higher order scheme such as MUSCL (Monotonic Upstreamcentered Scheme for Conservation Laws) and WENO (Weighted Essentially Non-Oscillatory) are proven to be effective to reproduce such steep gradient flow front [11]. Besides, higher order schemes with flux limiter are shown to be superior and better in mass conservation compared to lower-order scheme in solving the advection-diffusion shallow water equation [12]

In this study, a two-dimensional depth averaged model solved using higher order numerical scheme is developed to simulate the hyper-concentrated flow of fine suspension as representation of mudflow at mountainous area which is made up of a large amount of fine particle below $100 \mu m$ [13]. The friction slope which is formulated empirically by Coussot and Piau [13] for uniform laminar flow is used. The model is based on the Herschel-Bulkley model.

The goal of this numerical study is to develop a numerical model to simulate mudflow with good accuracy. This is achieved by using higher order scheme to solve the advection term so that the inertia term can be numerically reproduced correctly. Secondly, a suitable constitutive model is chosen to reproduce the rheological characteristic of mudflow.

The numerical model is verified in three stages. In the first stage, the model was verified against the partial dam-break flow on a dry bed problem. The stability and performance of the higher order schemes in solving the advection term are checked in the simulation of partial dam-break flow problem. In the second stage, the simulation of the release of Herschel-Bulkley fluid from a reservoir onto an inclined dry channel was carried out. The numerical results were compared against the experimental results by Cochard and Ancey [14]. The purpose of the second stage verification is to assess the suitability and accuracy of the constitutive equation. In the third stage, the overall performance of the numerical model was assessed by verifying it against experimental work on the release of mudflow on an inclined plane carried out by Laigle and Coussot [6]. Finally, the robustness and stability of the model were tested by simulating a simplified mudflow event with obstacles at the downstream.

\subsection{METHODOLOGY}

\subsection{Governing Equations}

The following depth-averaged continuity and momentum equations are used in the numerical model,

$$
\begin{aligned}
& \frac{\text { Continuity equation }}{\frac{\partial h}{\partial t}+\frac{\partial M}{\partial x}+\frac{\partial N}{\partial y}=0} \\
& \begin{array}{c}
\text { Momentum equation } \\
\frac{\partial M}{\partial t}+\frac{\partial u M}{\partial x}+\frac{\partial v M}{\partial y}= \\
-g h \frac{\partial z_{s}}{\partial x}-\frac{\tau_{b x}}{\rho}+\frac{\partial}{\partial x}\left(-\overline{u^{\prime 2}} h\right)+\frac{\partial}{\partial y}\left(-\overline{u^{\prime} v^{\prime}} h\right) \\
\frac{\partial N}{\partial t}+\frac{\partial u N}{\partial x}+\frac{\partial v N}{\partial y}= \\
-g h \frac{\partial z_{s}}{\partial y}-\frac{\tau_{b y}}{\rho}+\frac{\partial}{\partial x}\left(-\overline{u^{\prime} v^{\prime}} h\right)+\frac{\partial}{\partial y}\left(-\overline{v^{\prime 2}} h\right)
\end{array}
\end{aligned}
$$

where $t$ is time, $h$ is the flow depth, $(u, v)$ and $(M=$ $u h, N=v h$ ) are velocities and fluxes in $x$ and $y$ directions in Cartesian coordinate respectively. $z_{s}$ is the water surface elevation measured from the datum. $\tau_{b x}$ and $\tau_{b y}$ are bed shear stresses in $x$ and $y$ direction respectively. $g$ is the gravity acceleration and $\rho$ is the fluid density. In this study, only mudflow with highconcentration of mud is considered. Under high mud 
concentration, the flow can be regarded as laminar. Therefore, the Reynold shear stresses $-u^{\prime 2},-v^{\prime 2}$, and $-u^{\prime} v^{\prime}$ are neglected in the numerical model in the study.

\subsection{Constitutive Relation}

Coussot and Piau [13] showed that for hyperconcentrated fine suspension fluid, the flow characteristics can be reproduced by using HerschelBulkley model satisfactorily. The bottom and wall shear stresses are given by Coussot and Piau [13] by the following expression

$$
\begin{gathered}
\tau_{b i}=\tau_{y}\left[1+a\left(H_{b}\right)^{-0.9}\right] \\
a=1.93-0.43 \tan ^{-1}\left[\left(\frac{10 h}{B}\right)^{20}\right] \\
H_{b}=\frac{\tau_{y}}{K}\left(\frac{h}{u_{i}}\right)^{\frac{1}{3}}, \quad i=1,2
\end{gathered}
$$

where $B$ is the width of the rectangular channel, $\tau_{y}$ is the yield stress and $K$ is the Herschel-Bulkley fluid parameter. The subscript $i$ index in Eq. (3) can be interpreted such as follows: for $i=1, \tau_{b 1}=\tau_{b x}, u_{1}=u$ and for $i=2, \tau_{b 2}=\tau_{b y}, u_{2}=v$.

\subsection{Numerical Solution and Scheme}

The finite volume method (FVM) scheme is used to discretize the governing equations in Eq. (1), (2a) and (2b), where the discretized forms are shown in Eq. (4a), (4b), (5a) and (5b). The variables are defined using the staggered grid system as shown in Figure 1.

\section{Continuity equation}

$$
\begin{aligned}
\frac{\left(h_{i+\frac{1}{2}, j+\frac{1}{2}}^{n+1}-h_{i+\frac{1}{2}, j+\frac{1}{2}}^{n}\right)}{\Delta t} & +\frac{\left(M_{i+1, j+\frac{1}{2}}^{n}-M_{i, j+\frac{1}{2}}^{n}\right)}{\Delta x} \\
+ & \frac{\left(N_{i+\frac{1}{2}, j+1}^{n}-N_{i+\frac{1}{2}, j}^{n}\right)}{\Delta y}=0
\end{aligned}
$$

For the continuity equation, upwind scheme is used to evaluate the flux $M$ and $N$ as follows,

$$
\begin{aligned}
& M_{i+1, j+1 / 2} \\
& = \begin{cases}u_{i+1, j+1 / 2} h_{i+1 / 2, j+1 / 2} & \text { if } u_{i+1 j+1 / 2} \geq 0 \\
u_{i+1, j+1 / 2} h_{i+3 / 2, j+1 / 2} & \text { if } u_{i+1, j+1 / 2}<0\end{cases} \\
& N_{i+\frac{1}{2}, j+1}= \begin{cases}v_{i+\frac{1}{2}, j+1} h_{i+\frac{1}{2}, j+\frac{1}{2}} & \text { if } v_{i+\frac{1}{2}, j+1} \geq 0 \\
v_{i+\frac{1}{2}, j+1} h_{i+\frac{1}{2}, j+\frac{3}{2}} & \text { if } v_{i+\frac{1}{2}, j+1}<0\end{cases}
\end{aligned}
$$

Momentum equation

$$
\begin{aligned}
& \frac{\partial}{\partial t}\left(M_{i, j+\frac{1}{2}}\right)+\frac{(u M)_{i+\frac{1}{2}, j+\frac{1}{2}}^{n}-(u M)_{i-\frac{1}{2}, j+\frac{1}{2}}^{n}}{\Delta x}+\frac{(v M)_{i, j+1}^{n}-(v M)_{i, j}^{n}}{\Delta y} \\
& =-g h_{i, j+\frac{1}{2}}\left(\frac{h_{i+\frac{1}{2}, j+\frac{1}{2}} h_{i-\frac{1}{2}, j+\frac{1}{2}}}{\Delta x}+\frac{z_{b_{i+\frac{1}{2}}, j+\frac{1}{2}}-z_{b_{i-\frac{1}{2}} j+\frac{1}{2}}}{\Delta x}\right) \\
& -\frac{\operatorname{sign}\left(u_{i, j+\frac{1}{2}}\right) \tau b x i, j+\frac{1}{2}}{\rho} \\
& \frac{\partial}{\partial t}\left(N_{i+\frac{1}{2}, j}\right)+\frac{(u N)_{i+1, j}^{n}-(u N)_{i, j}^{n}}{\Delta x}+\frac{(v N)_{i+\frac{1}{2}, j+\frac{1}{2}}^{n}-(v N)_{i+\frac{1}{2}, j-\frac{1}{2}}^{n}}{\Delta y} \\
& =-g h_{i+\frac{1}{2}, j}\left(\frac{h_{i+\frac{1}{2}, j+\frac{1}{2}}-h_{i+\frac{1}{2}, j-\frac{1}{2}}}{\Delta y}+\frac{z_{b_{i+\frac{1}{2}}, j+\frac{1}{2}}-z_{b_{i+\frac{1}{2}}, j-\frac{1}{2}}}{\Delta y}\right) \\
& -\frac{\operatorname{sign}\left(v_{i+\frac{1}{2}, j}\right) \tau_{b y i+\frac{1}{2}, j}}{\rho}
\end{aligned}
$$

The function "sign" is a function defined as follows,

$$
\operatorname{sign}(x)=\left\{\begin{array}{c}
1 \text { if } x \geq 0 \\
-1 \text { if } x<0
\end{array}\right.
$$

$h_{i, j+\frac{1}{2}}$ and $h_{i+\frac{1}{2}, j}$ are defined as follows,

$$
\begin{aligned}
& h_{i, j+\frac{1}{2}}=\frac{1}{2}\left(h_{i+\frac{1}{2}, j+\frac{1}{2}}+h_{i-\frac{1}{2}, j+\frac{1}{2}}\right) \\
& h_{i+\frac{1}{\frac{1}{}^{\prime}}, j}=\frac{1}{2}\left(h_{i+\frac{1}{2^{\prime}}, j+\frac{1}{2}}+h_{i+\frac{1}{2^{2}}, j-\frac{1}{2}}\right)
\end{aligned}
$$

The subscript indices $i, j$ refer to the cell location as shown in Figure 1 and the superscript index $n$ represents the time step count. $\tau_{b x i, j+\frac{1}{2}}$ and $\tau_{b y i+\frac{1}{2}, j}$ are evaluated based on Eq. (3). (uM, uN) and (vM, vN) are momentum fluxes across the control volume boundary with their normal parallel to $x$ and $y$ directions respectively for quantity $M$ and $N$. A third order MUSCL [15] differencing method is used to solve the advection term. In order to satisfy TVD property, minmod flux limiter is applied [10]. The flux limiter is required for higher order numerical scheme to suppress numerical oscillation according to Godunov's theorem [16]. The time integration is solved using the second-order Adam-Bashfort method [10]. Upon solving Eq. (4a), (4b), (5a) and (5b), the new value for the velocities are calculated as follows,

$$
\begin{aligned}
& u_{i, j+\frac{1}{2}}^{n+1}=\frac{M_{i, j+\frac{1}{2}}^{n+1}}{h_{i-\frac{1}{2}+c}^{n+1}}, c=\left\{\begin{array}{l}
0 \text { for } M_{i, j+\frac{1}{2}}^{n+1} \geq 0 \\
1 \text { for } M_{i, j+\frac{1}{2}}^{n+1}<0
\end{array}\right. \\
& v_{i+\frac{1}{2}, j}^{n+1}=\frac{N_{i+\frac{1}{2}, j}^{n+1}}{h_{j-\frac{1}{2}+c}^{n+1}}, c=\left\{\begin{array}{l}
0 \text { for } N_{i+\frac{1}{2}, j}^{n+1} \geq 0 \\
1 \text { for } N_{i+\frac{1}{2}, j}^{n+1}<0
\end{array}\right.
\end{aligned}
$$




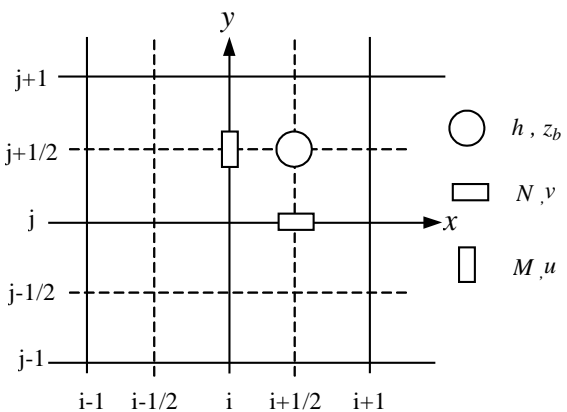

(a)

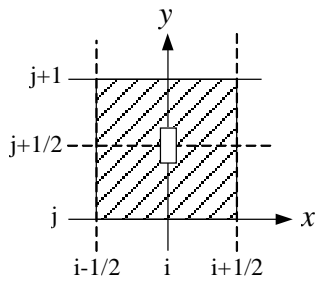

(b)

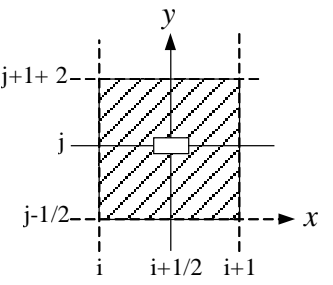

(c)

Figure 1 (a) Variables in the staggered mesh system used in the numerical model. (b) Definition of control volume for flux in xdirection for quantity $M$. (c) Definition of control volume for flux in y-direction for quantity $N$

\subsection{Verification of Numerical Model}

In this study, the numerical model was verified using partial dam-break flow problem which is one of the benchmarking problems to evaluate the performance of shallow water model $[17,18]$.

\subsubsection{Partial Dam-break Flow}

The simulation of a partial dam-break flow problem over a dry and wet bed (depth of wet bed is $5.0 \mathrm{~m}$ ) was carried out to check the stability and accuracy of the model before the shear stress terms from the rheological model were included. A rectangular reservoir with initial water depth of $10.0 \mathrm{~m}$ and width of $200.0 \mathrm{~m}$ was released onto a flat bed. The opening of the reservoir was set at $75.0 \mathrm{~m}$. The reservoir's opening was positioned at location $y=95.0 \mathrm{~m}$. The simulation condition is shown in Table 1.

\subsubsection{Simulation of the Release of Herschel-Bulkley Fluid on an Inclined Plane}

The constitutive relation for mudflow with high content of fines can be satisfactorily represented by the Herschel-Bulkley model [13]. In this study, the numerical model was verified against the experimental study by Cochard and Ancey [14] to evaluate the performance of the Herschel-Bulkley rheological relation given in Eq. (3). In the numerical test, a finite amount of Herschel-Bulkley fluid (Carbopol sample with concentration of $0.30 \%$ ) was released onto an inclined plane as shown in Figure 2.

In Cochard and Ancey [14] experiment, the fluid in the reservoir was released through an opening by pulling up the dam gate. The gate was pulled up to a desirable height $(30 \mathrm{~cm}$ to $36 \mathrm{~cm})$ in $0.8 \mathrm{~s}$ and the fluid flowed through the opening without being obstructed by the gate. However, the gate motion was not simulated because of the limitation of depthaveraged model. The fluid at the reservoir was released instantaneously without the dam gate in the numerical model. The schematic of the numerical simulation is shown in Figure 2. The simulation conditions and rheological properties of the Herschel-Bulkley fluid used in the experiment and numerical model are shown in Table 2.

\subsubsection{Simulation of the Release of Mudflow on an Inclined Plane}

A simulation of mudflow on an inclined bed based on the experiment by Laigle and Coussot [6] was carried out to assess the overall performance of the numerical model. In the experiment, a finite amount of water-clay mixture retained behind a dam gate was released instantaneously onto an inclined rectangular channel. The width of the rectangular channel was $0.6 \mathrm{~m}$ and the slope of the channel was set at $16 \%$. The water-clay mixture was contained between the dam gate (at abscissa $x=x_{\text {dam }}=0.85$ $\mathrm{m}$ ) and the upstream channel wall (at abscissa $x=0$ $\mathrm{m})$. The maximum depth of the water-clay mixture in the reservoir was $h_{o}=0.13 \mathrm{~m}$. The initial setup is shown in Figure 2 and the numerical simulation condition and the rheological properties of the water-clay mixture (mud) are based on the experiment by Laigle and Coussot [6] as shown in Table 3. The flow depth gauges were installed at abscissa $x=1.65 \mathrm{~m}$ (Gauge 1), $2.75 \mathrm{~m}$ (Gauge 2) and $3.85 \mathrm{~m}$ (Gauge 3) for flow depth observation.

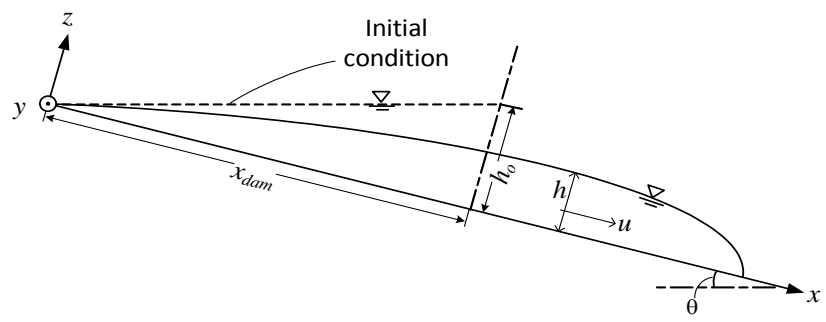

Figure 2 Release of mudflow over an inclined channel 
Table 1 Simulation conditions for partial dam-break flow

\begin{tabular}{|l|c|}
\hline Mesh size & $\Delta x=\Delta y=5 \mathrm{~m}$ \\
\hline Domain size & $200.0 \mathrm{~m} \times 200.0 \mathrm{~m}$ \\
\hline Time interval, $\Delta t$ & $1 \times 10^{-3} \mathrm{~s}$ \\
\hline Downstream depth, for dry bed & $1 \times 10^{-6} \mathrm{~m}$ \\
\hline Downstream depth, for wet bed & $5.0 \mathrm{~m}$ \\
\hline
\end{tabular}

Table 2 Simulation conditions and rheological properties of Herschel-Bulkley fluid

\begin{tabular}{|l|c|}
\hline Mesh size & $\Delta x=\Delta y=0.01 \mathrm{~m}$ \\
\hline Domain size & $\begin{array}{c}2.60 \mathrm{~m} \text { in } x \text {-direction } \\
1.80 \mathrm{~m} \text { in } y \text {-direction }\end{array}$ \\
\hline Time interval, $\Delta t$ & $1 \times 10^{-5} \mathrm{~s}$ \\
\hline Bed slope & $12^{\circ}$ \\
\hline Reservoir length, $x_{\text {dam }}$ & $0.51 \mathrm{~m}$ \\
\hline Reservoir width & $0.30 \mathrm{~m}$ \\
\hline Depth of fluid in reservoir, $h_{o}$ & $0.34 \mathrm{~m}$ \\
\hline Yield stress, $\tau_{y}$ & $89.0 \mathrm{~Pa}$ \\
\hline Density, $\rho$ & $1020.0 \mathrm{kgm}^{-3}$ \\
\hline Fluid index, $n$ & 0.415 \\
\hline Plastic viscosity, $\eta$ & $47.68{\mathrm{~Pa} . \mathrm{s}^{0.415}}^{0.45}$ \\
\hline
\end{tabular}

\subsubsection{Simplified Mudflow Event}

After verification, the numerical model was used to simulate a simplified mudflow event where the mudflow was released from a reservoir onto an inclined bed with several obstacles placed at the downstream of the reservoir. The purpose of the simulation is to check the robustness and stability of the model in the presence of obstacles. The obstacles were introduced by raising the elevation of the bed. Simulation conditions are shown in Table 4.

\subsection{RESULTS AND DISCUSSIONS}

\subsection{Partial Dam-break Flow}

The simulation results of partial dam-break flow over dry and wet bed are shown in Figure 3 and Figure 4 respectively. Although there is no analytical solution for comparison, the numerical model performance was compared qualitatively against the numerical result of a two-dimensional depth-averaged finitevolume model by Caleffi et al. [19].

Numerical results show that the flow depth profile and contour do not differ much from the result of Caleffi et al.'s model [19]. As the initial stage of dam break flow is governed by dominant inertial characteristics [21], the good agreement between both models shows that the model developed in this study could solve the advection term in the momentum equation (Eq. 2(a) and 2(b)) satisfactorily using higher order scheme.

\subsection{Simulation of the Release of Herschel-Bulkley Fluid on an Inclined Plane}

Flow profiles from the numerical simulation are shown in Figure 5. Flow depth and discharge per unit width were observed at selected points in the numerical model, namely station 1, 2 and 3 . The location of the observation stations are shown in Figure 5 and their respective temporal variations are shown in Figure 6 and 7 .

Table 3 Simulation conditions and rheological properties of mudflow based on experiment by Laigle and Coussot [6]

\begin{tabular}{|l|c|}
\hline Mesh size & $\Delta x=\Delta y=0.05 \mathrm{~m}$ \\
\hline Domain size & $\begin{array}{c}x=3.00 \mathrm{~m} \\
y=0.60 \mathrm{~m}\end{array}$ \\
\hline Time interval, $\Delta t$ & $1 \times 10^{-6} \mathrm{~s}$ \\
\hline Bed slope & $16^{o}$ \\
\hline Reservoir length, $x_{\text {dam }}$ & $0.85 \mathrm{~m}$ \\
\hline Reservoir width & $0.60 \mathrm{~m}$ \\
\hline Depth at reservoir, $h_{o}$ & $0.34 \mathrm{~m}$ \\
\hline Yield stress, $\tau_{y}$ & $19.0 \mathrm{~Pa}$ \\
\hline Density, $\rho$ & $1410 \mathrm{kgm}^{-3}$ \\
\hline Fluid index, $n$ & 0.33 \\
\hline Plastic viscosity, $\eta$ & $3.5{\mathrm{~Pa} . \mathrm{s}^{0.33}}^{0}$ \\
\hline
\end{tabular}

Table 4 Simulation conditions and rheological properties of mudflow for simulation of simplified mudflow event

\begin{tabular}{|l|c|}
\hline Mesh size & $\Delta x=\Delta y=5 \mathrm{~m}$ \\
\hline Domain size & $\begin{array}{c}x=400 \mathrm{~m} \\
=270 \mathrm{~m}\end{array}$ \\
\hline Time interval, $\Delta t$ & $1 \times 10^{-3} \mathrm{~s}$ \\
\hline Bed slope & $12^{\circ}$ \\
\hline Reservoir length, $x_{\text {dam }}$ & $100 \mathrm{~m}$ \\
\hline Reservoir width & $270 \mathrm{~m}$ \\
\hline Depth at reservoir, $h_{o}$ & $10.0 \mathrm{~m}$ \\
\hline Yield stress, $\tau_{y}$ & $19.0 \mathrm{~Pa}$ \\
\hline Density, $\rho$ & $1410.0 \mathrm{~kg} \mathrm{~m}^{-3}$ \\
\hline Fluid index, $n$ & 0.33 \\
\hline Plastic viscosity, $\eta$ & $3.5 \mathrm{~Pa} . \mathrm{s}^{0.33}$ \\
\hline
\end{tabular}

The temporal variation pattern at station 1 and 2 shows the peak values which correspond to the arrival of the flow. Both stations are situated along the longitude direction of the flow. Similar temporal variation pattern can be seen in the work of Laigle and Coussot [6] and Schippa and Pavan [20]. At the later stage of the flow, the viscous-pressure equilibrium will be more dominant than the inertiapressure equilibrium [21]. This phenomenon is also valid for fluid with yield stress [22]. In addition, fluid with yield stress will reach a complete halt [22]. Therefore, it is reasonable to use the final contact line to evaluate the numerical model performance in translating the constitutive relation into the viscoplastic characteristic of the flow. Contact line is 
the line demarcating the boundary between the fluid and the dry bed. The experimental data from the work of Cochard and Ancey [14] for the case of Carbopol with $0.3 \%$ concentration was used for comparison. Gate pulling effect in the experiment

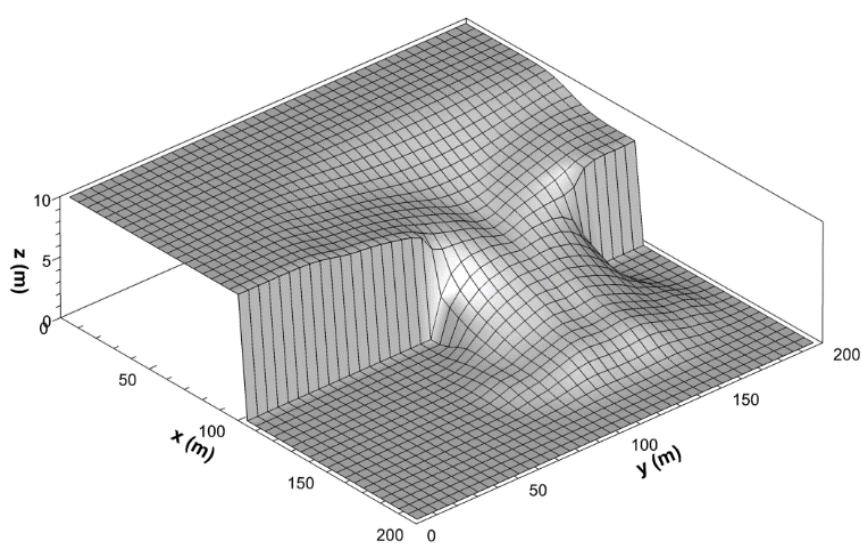

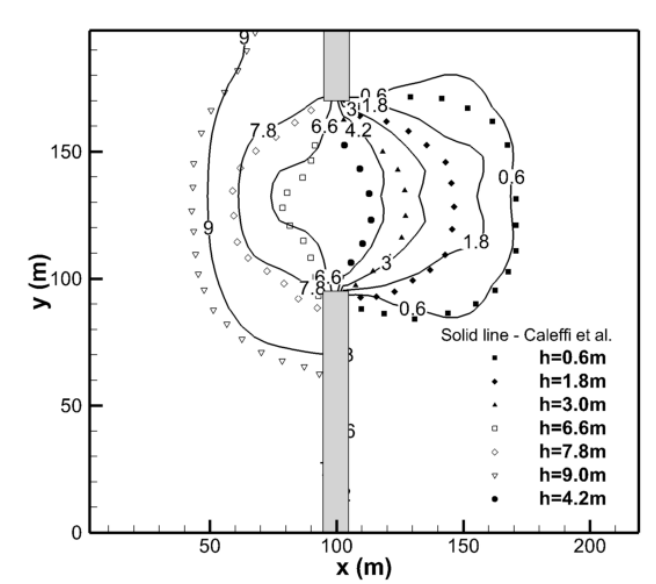

Was not considered in the numerical model. The final contact line when the flow came to a complete halt at $t=10 \mathrm{~s}$ is shown in Figure 8.

Figure 3 Partial dam-break problem over dry bed at $\dagger=6.0 \mathrm{~s}$
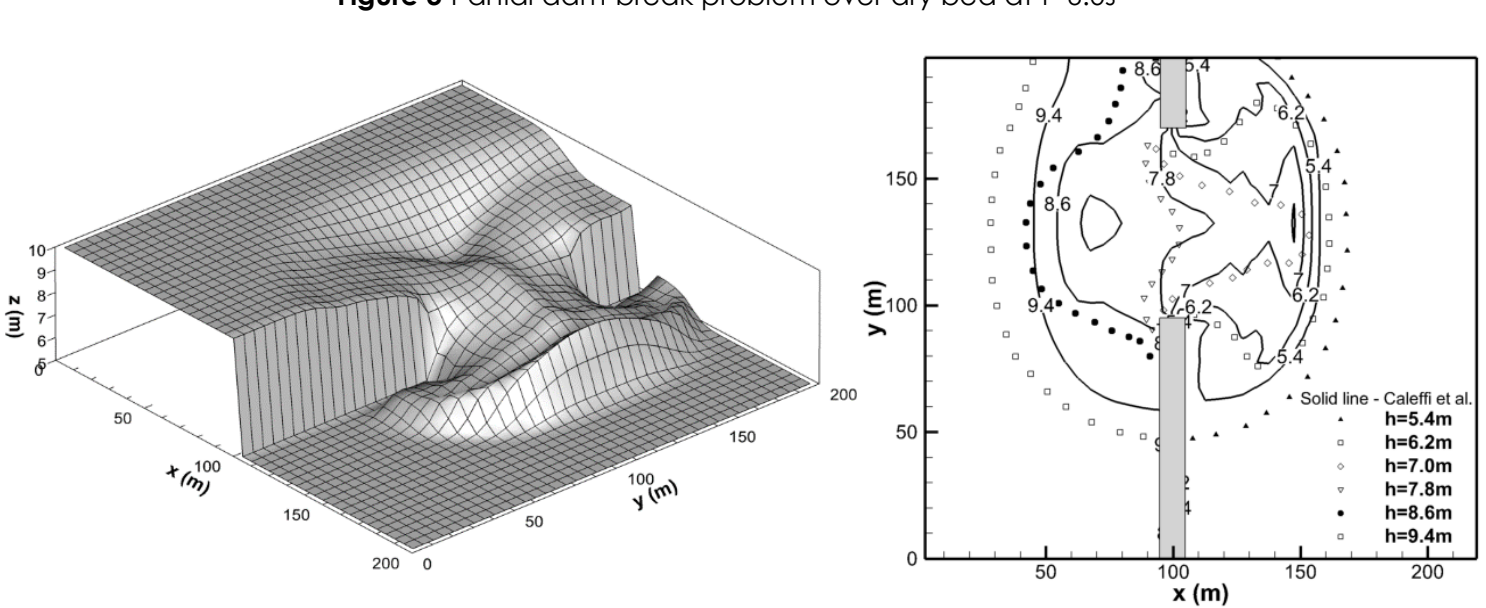

Figure 4 Partial dam-break problem over wet bed at $t=6.0 \mathrm{~s}$

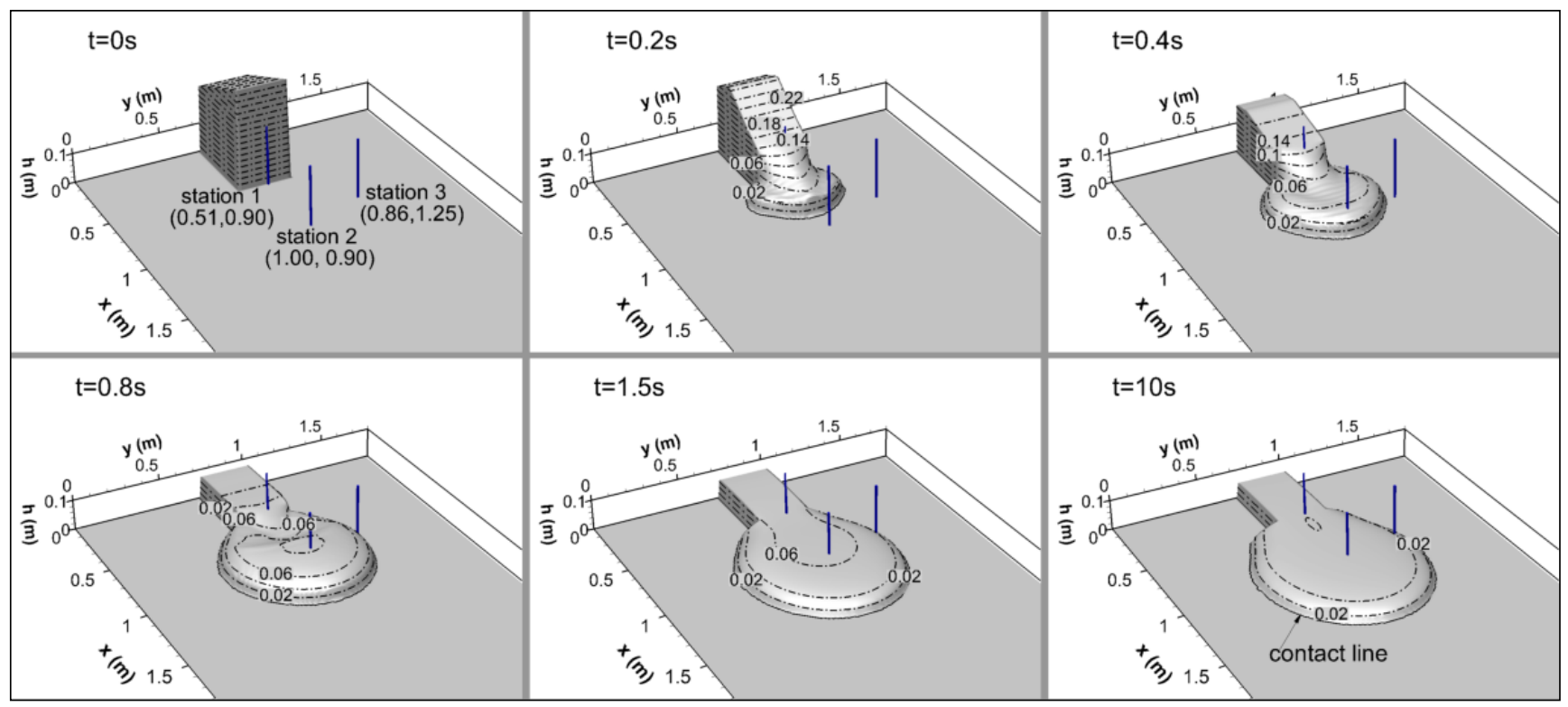

Figure 5 Bird's eye view of Herschel-Bulkley fluid flow over an inclined bed 


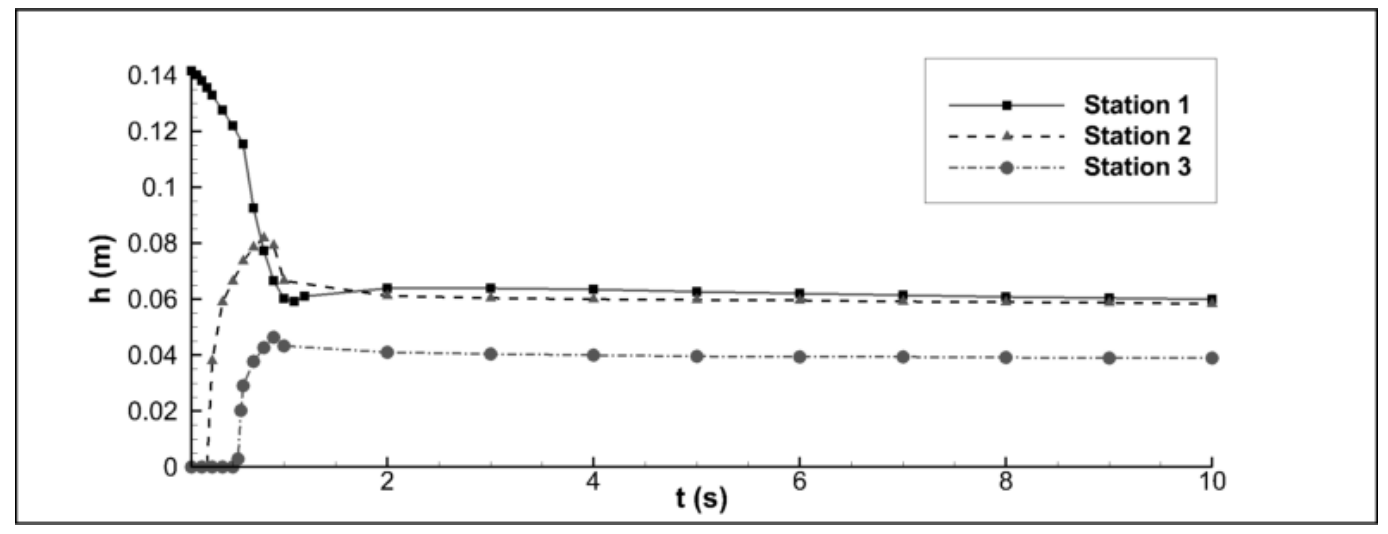

Figure 6 Temporal variation of flow depth $h$ at gauge stations

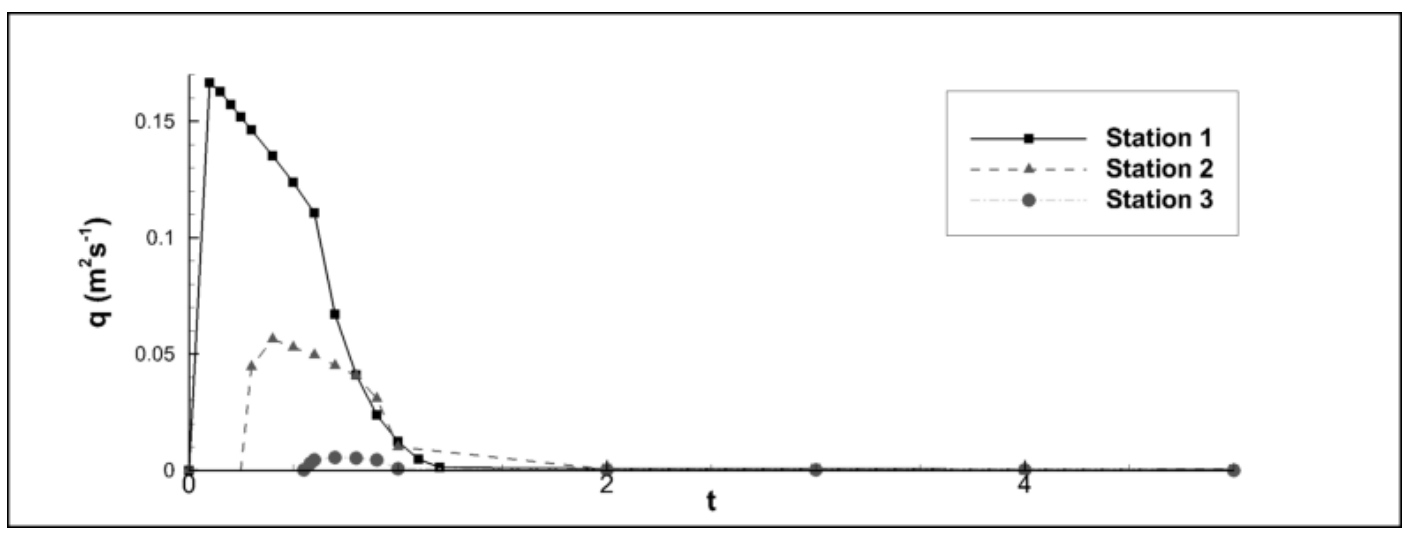

Figure 7 Temporal variation of discharge per unit width $q$ at gauge stations

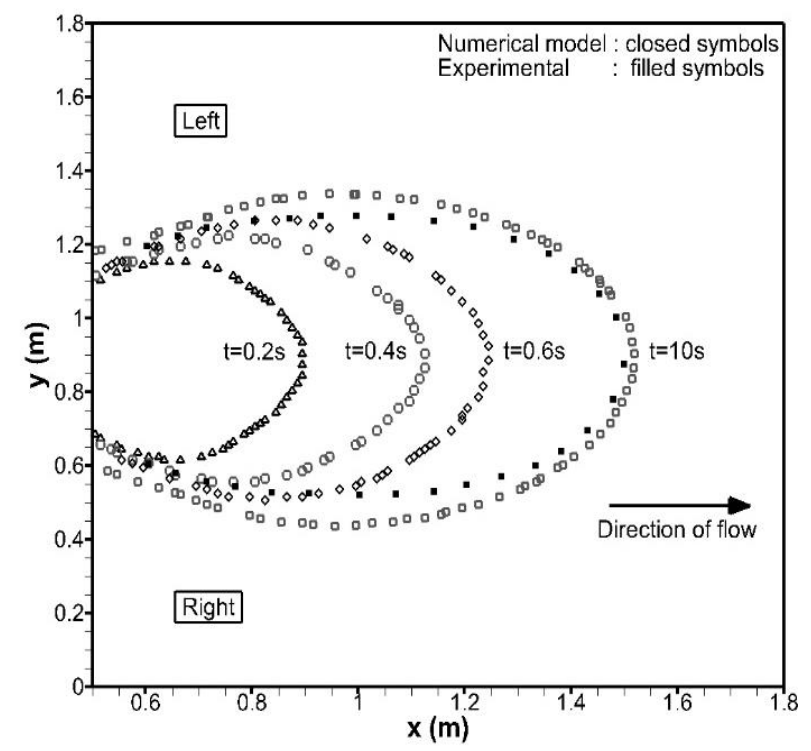

Figure 8 Contact lines of Herschel-Bulkley fluid at $t=0.2 \mathrm{~s}$ $t=0.4 \mathrm{~s}, \mathrm{t}=0.6 \mathrm{~s}$ and $\mathrm{t}=10 \mathrm{~s}$

The percentage difference between the numerical and experimental result is defined in Eq. 7 and used to evaluate the performance of the numerical model. The performance of the numerical model in reproducing the final contact line position of the fluid is shown in Figure 9.
Percentage difference $=\frac{\mid \text { Numerical }- \text { Experimental } \mid}{\text { Experimental }} \times 100(7)$

From the line gradient in Figure 9, it can be concluded that the numerical model overpredicted the final contact line position by an average of $15 \%$ when compared to the experimental data. This discrepancy is contributed by the overprediction of lateral spreading as shown in Figure 8. The maximum difference for the lateral spreading lengths are $15 \%$ (left hand side boundary) and 22\% (right hand side boundary). However, the model performed excellently in terms of the reproduction of longitudinal spreading length where a $2 \%$ difference was observed. The maximum lateral and longitudinal spreading length are summarized in Table 5. Therefore, it can be concluded that the numerical model can reproduce the characteristic in the viscous-pressure equilibrium flow stage as well as the effect of yield stress correctly. Thus, the constitutive relation used in the numerical model is suitable for the simulation of Herschel-Bulkley fluid. 


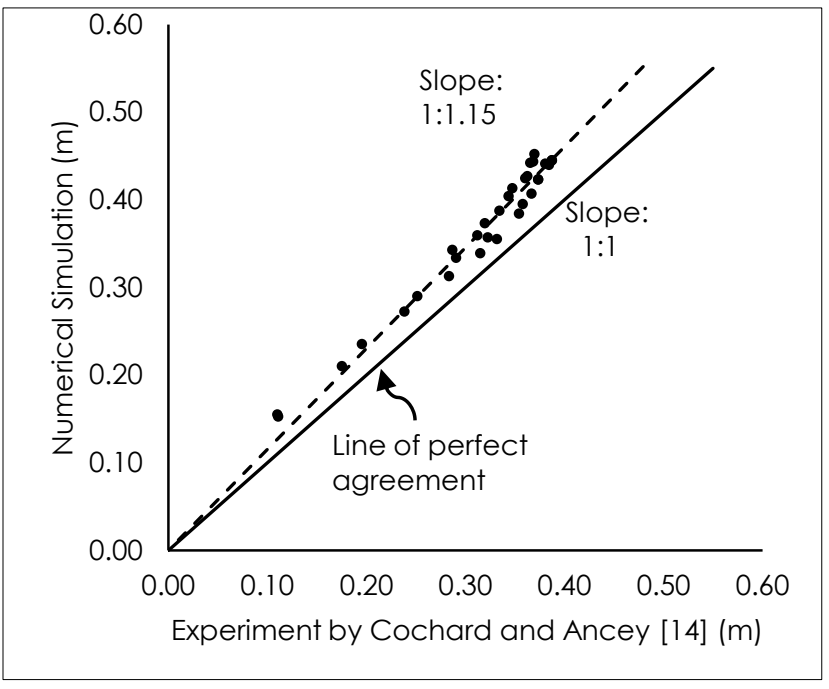

Figure 9 Performance of numerical model in terms of final contact line of fluid at $t=10$ s

Table 5 Discrepancies between numerical results and experimental data [14] for final contact line position

\begin{tabular}{|c|c|c|c|}
\hline \multirow{2}{*}{ Final contact line } & \multicolumn{2}{|c|}{ Lateral } & \multirow{2}{*}{ Longitudinal } \\
\cline { 2 - 3 } & (Left side) & (Right side) & \\
\hline Experiment $(\mathrm{m})$ & 0.388 & 0.370 & 0.875 \\
\hline Numerical $(\mathrm{m})$ & 0.445 & 0.452 & 0.895 \\
\hline Difference \% & 15 & 22 & 2 \\
\hline
\end{tabular}

3.3 Simulation of the Release of Mudflow on an Inclined Plane

Results for the simulation of the release of mudflow on an inclined plane based on the experiment by Laige and Coussot [6] is shown in Figure 10. The numerical model performed well in terms of the reproduction of flow depth and speed. The discrepancies between numerical results and experimental data are presented in Table 6. The flow speed is evaluated in terms of wave arrival time at the gauges. The discrepancies between the numerical and experimental result on first wave arrival time, $t_{f w}$ are within an acceptable range; Gauge 1 recorded largest difference of $12.5 \%$ (late arrival), Gauge 2 and 3 recorded earlier arrival with $7.9 \%$ and $5.6 \%$ difference, respectively. In the case of the peak wave arrival time, $t_{p w}$ (time when maximum flow depth arrives), the largest difference was recorded at Gauge 3 (by 16.2\% earlier than the experimental observation). The differences at Gauge 1 and 2 are $11.8 \%$ and $8.9 \%$ respectively. The numerical model performed satisfactorily in terms of the prediction of the depth of peak wave, $h_{p}$ (maximum flow depth). Excellent agreements between the numerical and experimental result were observed at Gauge 2 and 3 with $0.07 \%$ and $2.9 \%$ underprediction respectively. The largest discrepancy for $h_{p}$ is at Gauge 1, with $8.8 \%$ underprediction.
For final flow depth, $h_{f}$, Gauge 2 and 3 recorded an underprediction of $4.1 \%$ and $5.6 \%$ respectively.

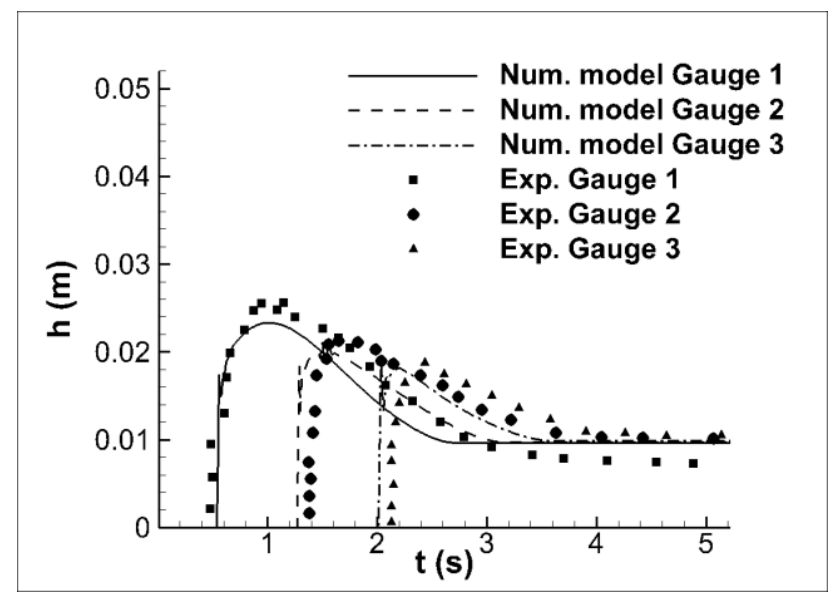

Figure 10 Temporal flow depth recorded at three different locations after dam-break flow is initiated

Table 6 Discrepancies between numerical results and experimental data for temporal flow depth

\begin{tabular}{|c|c|c|c|}
\hline & Gauge 1 & Gauge 2 & Gauge 3 \\
\hline$t_{f w}$ & $12.5 \%$ & $7.9 \%$ & $5.6 \%$ \\
\hline$t_{p w}$ & $11.8 \%$ & $8.9 \%$ & $16.2 \%$ \\
\hline$h_{p}$ & $8.8 \%$ & $0.07 \%$ & $2.9 \%$ \\
\hline$h_{f}$ & $32.4 \%$ & $4.1 \%$ & $5.6 \%$ \\
\hline
\end{tabular}

However, the numerical model overpredicted the final flow depth at Gauge 1 with a difference of $32.4 \%$. This large discrepancy deserves further investigation, especially to carry out additional verification against other literature data. Except for Gauge 1, there is an overall good agreement of final flow depth between the numerical model and the experimental data.

Hence, it can be concluded that the inertial and viscoplastic characteristics were well reproduced in the numerical model with the timely arrival of the peak wave and acceptable prediction of the maximum and final flow depth.

\subsection{Simulation of Simplified Mudflow Event}

The flow depth contour after the release of the mudflow from the reservoir at $t=120 \mathrm{~s}$ is shown in Figure $11(\mathrm{a})$ and $11(\mathrm{~b})$. The robustness of the numerical model was demonstrated as there was no numerical instability or unphysical flow feature observed in the simulation. It can be concluded that the numerical model can be extended to include topography and building data for more realistic mudflow scenario simulation. 


\subsection{CONCLUSION}

In this study, a higher-order two-dimensional depthaveraged model based on finite volume method was developed to simulate mudflow. Mudflow with high content of fines was simulated with the adoption of Herschel-Bulkley constitutive model. The numerical model was initially verified against a partial dam-break problem to assess its accuracy and performance of its higher-order scheme in solving the advection term. To assess the performance of the translation of the constitutive relation into the rheological behavior of Herschel-Bulkley fluid, the model was compared against the experimental data of the release of viscoplastic fluid onto inclined plane.

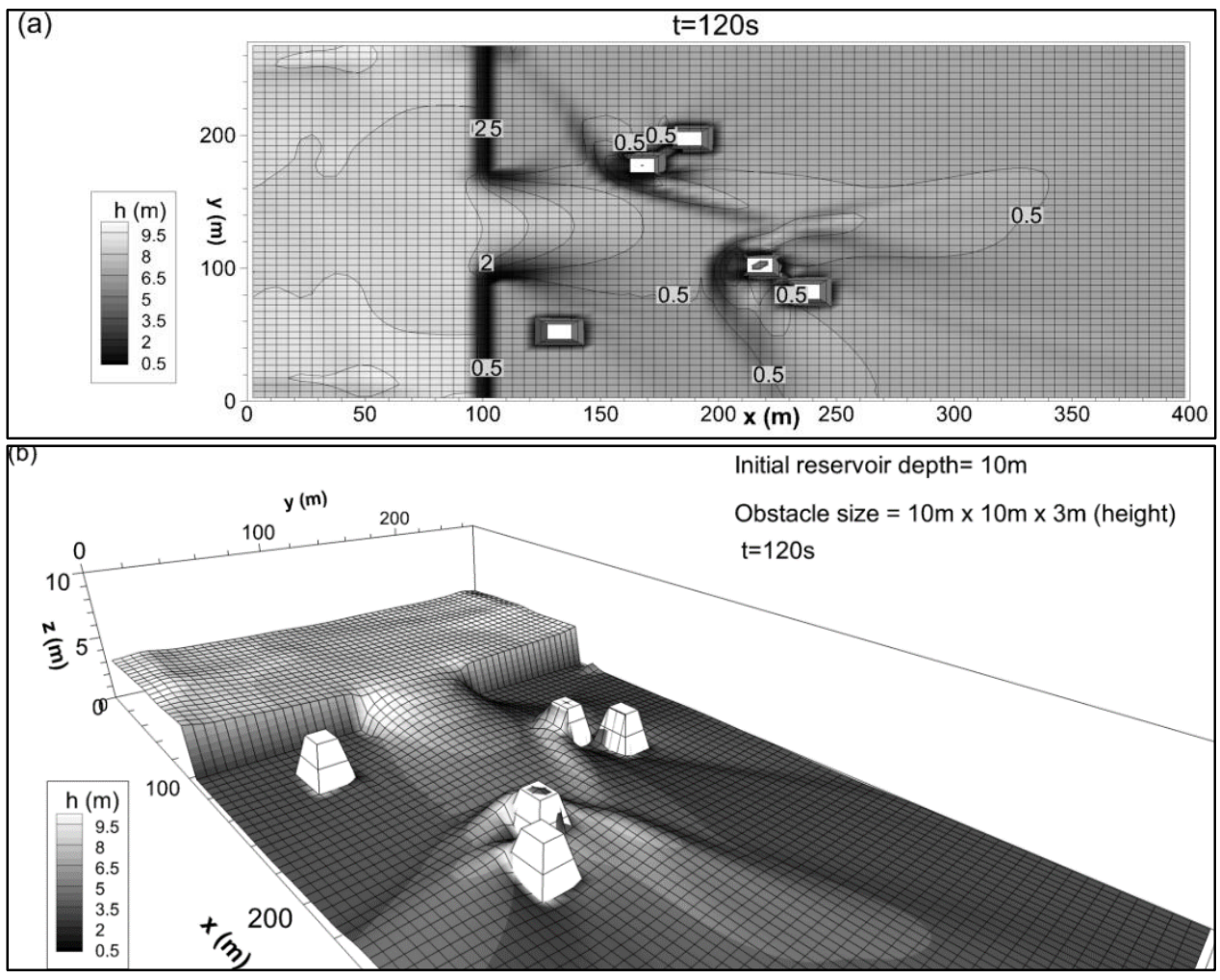

Figure 11 Flow depth contour a simplified mudflow event with obstacles at the downstream of the reservoir

The final longitudinal spreading length was well reproduced in the numerical model with $2 \%$ difference compared to the experimental data. The overall performance of the model was satisfactory with good prediction of wave speed; arrival of first wave with maximum of $12.5 \%$ difference and arrival of peak wave with maximum of $16.2 \%$. The depth of peak wave was also well reproduced in the numerical model with maximum of $8.8 \%$ difference and minimum of $0.07 \%$ difference. The final flow depths were well predicted (minimum $4.1 \%$ difference), except for gauge 1 which overpredicted the flow depth by $32.4 \%$. The robustness of the numerical model was demonstrated through the simulation of a simplified mudflow event.

\section{Acknowledgement}

The authors express gratitude to the Malaysian Ministry of Higher Education (MOHE) for 2015
Transdisciplinary Research Grant Scheme (TRGS) grant entitled "Land-use and land-cover: Development of a two-dimensional numerical model for mudflow with application on flood routing with the incorporation of mudflow".

\section{References}

[1] Costa, John E. 1984. Physical Geomorphology of Debris Flows. Developments and Applications of Geomorphology. Berlin: Springer-Verlag.

DOI: https://doi.org/10.1007/978-3-642-69759-3_9.

[2] Jamaludin, S., Abdullah, C. H. and Kasim, N. 2014. Rainfall Intensity and Duration for Debris Flow Triggering in Peninsular Malaysia. Landslide Science for a Safer Geoenvironment. 1: 167-174.

DOI: https://doi.org/10.1007/978-3-319-04999-1_20.

[3] Schamber, D. R. and MacArthur, R. C. 1985. Onedimensional Model for Mudflows. Proceeding of the Conference on Hydraulics and Hydrology in Small Computer Age, ASCE. Orlando, Florida. 2: 1334-1339.

[4] O'Brien, J. S. and Fullerton, W. T. 1990. Urban Floodplain and Alluvial Fan Stormwater Modeling. Urban Hydrology. 
Proceeding, 26th Annual AWRA Conference. Denver, Colorado.

[5] Takashi, T. and Tsujimoto, H. 1985. Delineation of the Debris Flow Hazardous Zone by a Numerical Simulation Method. Proceeding of the International Symposium on Erosion, Debris Flow and Disaster Prevention. Tsukuba, Japan. 457462.

[6] Laigle. D. and Coussot. P. 1997. Numerical Modeling of Mudflows. Journal of Hydraulic Engineering, ASCE. 123: 617-623.

DOI: https://doi.org/10.1061/(ASCE)0733-9429(1997)123:7 (617).

[7] Huang X. and Garcia, M. H. 1998. A Herschel-Bulkley Model for Mud Flow Down a Slope. Journal of Fluid Mechanics. 374: 305-333. DOI: https://doi.org/10.1017/S0022112098002845.

[8] Fernández-Nieto, E. D., Gallardo, J. M. and Vigneaux, P. 2014. Efficient Numerical Schemes for Viscoplastic Avalanches. Part 1: The 1D Case. Journal of Computational Physics. 264: 55-90. DOI: https://doi.org/10.1016/j.jcp.2014.01.026.

[9] Ionescu, I. and Lupaşcu, O. 2016. Modeling Shallow Avalanche Onset Over Complex Basal Topography. Advances in Computational Mathematics. 42(1). DOI: https://doi.org/10.1007/s10444-015-9407-2.

[10] Tannehill. J. C., Anderson. D. A. and Pletcher. R. H. 1997 Computational Fluid Mechanics and Heat Transfer. United States: Taylor and Francis.

[11] Griffiths, Graham W., and William E. Schiesser. 2009. Linear and Nonlinear Waves. Scholarpedia. 4(7): 4308. DOI: https://doi.org/10.4249/scholarpedia.4308.

[12] Pereira, F. F., Fragoso Jr, C. R., Uvo, C. B., Collischonn, W. \& Motta Marques, D. M. L. 2013. Assessment of Numerical Schemes for Solving the Advection-diffusion Equation on Unstructured Grids: Case Study of the Guaíba River, Brazil. Nonlinear Processes in Geophysics. 20(6): 1113-1125. DOI: https://doi.org/10.5194/npg-20-1113-2013.

[13] Coussot. P. and Piau. J. M. 1994. On the Behavior of Fine Mud Suspensions. Rheologica Acta. 33: 175-184. DOI: https://doi.org/10.1007/BF00437302.
[14] Cochard. S., and Ancey. C. 2009. Experimental Investigation of the Spreading of Viscoplastic Fluids on Inclined Planes. Journal of Non-Newtonian Fluid Mechanics. 158: 73-84.

DOI: https://doi.org/10.1016/j.jnnfm.2008.08.007.

[15] Van Leer. B. 1979. Towards the Ultimate Conservative Difference Scheme. V. A Second-Order Sequel to Godunov's Method. Journal of computational Physics. 32(1): 101-136. DOI: https://doi.org/10.1016/0021-9991 (79)90145-1.

[16] Toro. E. F. 2009. Riemann Solvers and Numerical Methods for Fluid Dynamics: A Practical Introduction. United States: Springer. DOI: https://doi.org/10.1007/b79761.

[17] Akoh, R., li, S. and Xiao, F. 2008. A CIP/multi-moment Finite Volume Method for Shallow Water Equations with Source Terms. International Journal For Numerical Methods in Fluids. 56(12): 2245-2270.

DOI: https://doi.org/10.1002/fld.1616.

[18] Erduran, K. S., Kutija, V. and Hewett, C. J. M. 2002 Performance of Finite Volume Solutions to the Shallow Water Equations with Shock - Capturing Schemes. International Journal For Numerical Methods in Fluids. 40(10): 1237-1273. DOI: https://doi.org/10.1002/fld.402.

[19] Caleffi. V., Valiani, A., and Zanni, A. 2003 Finite Volume Method for Simulating Extreme Flood Events. Journal of Hdyraulic Research. 41 (2): 167-177. DOI: https://doi.org/10.1080/00221680309499959.

[20] Schippa. L., and Pavan. S. 2011. Numerical Modelling of Catastrophic Events Produced by Mud or Debris Flows. Journal of Safety and Security Engineering. 4: 403-423. DOI: 10.2495/SAFE-V1-N4-403-422.

[21] Puay H. T. and Hosoda T. 2007. Study of Characteristics of Inertial and Viscous Flow Regions by Means of Dam Break Flow with Finite Volume. Journal of Applied Mechanics, JSCE. 10: 757-768. DOI: https://doi.org/10.2208/journalam.10.757.

[22] Puay H. T. and Hosoda T. 2010. Fundamental Study of Bingham Fluid by Means of Dam-break Flow Model. Journal of Hydraulic Engineering, JSCE. 54: $1177-1$. 